\title{
Full-Time Employment and Marital Satisfaction among Women in East Asian Societies
}

\author{
Makiko Hori \\ Department of Social, Cultural, and Justice Studies, University of Tennessee, \\ Chattanooga, USA \\ makiko-hori@utc.edu
}

\begin{abstract}
Using the 2006 East Asian Social Survey, the current study examines the relationship between wives' employment status and their marital satisfaction in China, Japan, South Korea, and Taiwan. The results show that full-time housewives are more satisfied as compared to full-time employed wives in Taiwan, while part-time employed wives are less satisfied than full-time employed wives in China. Wives' marital satisfaction is also associated with their gender role attitudes, husband's housework participation, and a number of family members in Japan and South Korea. The relationship between wives' employment and their marital satisfaction varies even among four East Asian countries, where gender climate is relatively similar.
\end{abstract}

\section{Keywords}

marital satisfaction - gender roles - East Asia

\section{Introduction}

While more equal gender relations have been accomplished in many parts of the world, gender is still a significant indicator of our behaviors and life experiences. This is especially true in societies with more traditional gender

* An earlier version was presented at the 2016 Southern Sociological Society meeting in Atlanta. I thank Sally Robicheaux for providing excellent advice and support throughout the completion of this article. 
norms. Traditional gender roles - domestic responsibilities for women and breadwinning responsibilities for men - are valued and emphasized, and nonconformity to these roles is subject to severe social sanctions in these countries. Therefore, the cultural definition of gender affects not only people's behaviors but also their mental states even more so in these countries.

Although some countries still follow traditional gender relations more rigidly than others, financial realities for many households have changed around the world. While wives are still expected to be the primary caregivers, and husbands the breadwinners of the household, many households nowadays also need the second income brought in by working wives. How strong this demand is may depend on, not only the conditions surrounding the family finances, but also the gender climate of the society, as well as, whether women's employment is normative or not. In more traditional countries, being a housewife may be still normative, and married women's employment may be negatively associated with their psychological well-being, even when the household needs the second income.

The current investigation focuses on one of these geographic areas with more traditional gender relations - East Asian countries. It also centers on married women and the relationship between their employment status and their marital satisfaction, which is one domain of overall life satisfaction. By focusing on the specific domain of life satisfaction and countries with more traditional gender climate, this study may be able to capture this relationship more clearly. Is being a housewife still the norm and does it increase married women's satisfaction in more male-dominated societies? What other factors are associated with married women's subjective well-being in East Asian countries? This research makes unique contributions to understanding how a macro-level gender climate, specifically East Asian contexts, may condition the relationship between non-traditional female roles and subjective well-being.

\section{Women's Employment and Their Well-Being}

Women's employment has become much more common globally. Therefore, research concerning social roles and the impact of women's employment on various outcomes has proliferated. In general, the previous research has shown that while employment provides women with more economic and noneconomic resources, it may conflict with other roles that women have traditionally fulfilled, such as family responsibilities. Hence, it is possible that its effect may be positive or negative on their psychological well-being. This section 
reviews the theoretical background that women's employment may have conflicting effects on their well-being.

\section{Positive Effects of Women's Paid Employment}

There are many aspects of employment that have been shown to have a positive association with psychological well-being. First, paid employment typically brings financial stability to women, leading them to have more negotiating power that they can utilize in their marriage. For example, husbands with fulltime employed wives tend to participate more in domestic work and childcare (Bianchi et al. 2000; Coltrane 2000).

In addition, wives' employment provides not only economic resources but also non-economic resources such as increased social networks established through the workplace, and role expansion. Paid employment may add chances to build social capital outside kin-networks, which is also an important source of social support (Moore 1990; Ross, Mirowsky, and Goldsteen, 1990). Role theory suggests that having multiple roles may produce positive outcomes, while having fewer roles may cause depression or distress when one perceives he/ she fails to fulfill those few roles sufficiently (Barnett and Hyde 2001; Marks and MacDermid 1996; Thoits 1983). Being able to make a monetary contribution to the household income may also be seen as being more socially valued, which may be positively associated with women's psychological well-being.

\section{Negative/Conflicting Effects of Women's Paid Employment}

Possible advantages of employment may in turn be conflicting with married women's life experiences and responsibilities. For example, time bind, caused by an inflexible work schedule or long work hours, may negatively impact women's well-being due to work-family conflict, especially when they are engaged in full-time employment (Allen et al. 2000; Demerouti and Geurts 2004; Hill et al. 2004). Although it depends on the type of occupation the person holds, the lack of flexibility in paid employment (e.g., specificity of work hours, travel required by employment, lack of daycare) may also be dissatisfying for working wives (Ross and Reskin 1992). Meanwhile, scholars have argued that domestic work provides wives with personal gratification, and thus it is rewarding (e.g., DeVault 1991). In this scenario, full-time housewives are expected to have a higher level of satisfaction as compared to wives with paid employment.

Moreover, being a full-time housewife may be positively related to women's satisfaction because fulfilling women's traditional gender roles is normative and complies with social expectations. Even in Western societies, where a greater degree of gender equality has been accomplished, women are still the primary caretakers of home and children, and therefore full-time housewives 
are not subject to social sanctions. On the other hand, employed wives, especially those who work in male-dominated occupations, may experience gender discriminations, in addition to juggling work and family responsibilities.

While literature over the relationship between wives' employment and their well-being has focused on contrasting advantages/disadvantages between full-time employment and full-time wifehood, there has been little debate regarding the effect of part-time employment on women's well-being. Although part-time employment may seem to be a better option for wives who hold primary family responsibilities, jobs that people typically work for part-time are often marginal, with limited opportunities for promotion or with no access to fringe benefits (Tilly 1996). The previous studies regarding the effect of part-time work have shown mixed results (Booth and Van Ours 2009, 2013; Tilly 1996). Therefore, paid employment, whether full-time or part-time, may have both positive and negative effects on wives' well-being.

\section{Recent Studies regarding Women's Employment and Well-Being}

Previous research regarding women's participation in the labor market and their well-being in western societies has been inconclusive, and studies have documented a positive, negative or neutral effect of women's employment on overall well-being and marital quality (Campione 2008; Klumb and Lampert 2004; Nomaguchi, Milkie, and Bianchi 2005; Wilk 2001). According to Stevenson and Wolfers (2009), subjective well-being among women in the U.S. has declined over the last 35 years, although employment, in their study, did not make any difference in women's subjective well-being. Meanwhile, Wilk's (2001) study, which utilized longitudinal data from Canadian mothers, showed that transition into employment decreased the level of distress of mothers. While in a more recent study, Booth and van Ours (2013) found that Dutch women have a high level of job satisfaction when they work part-time. Using data from 28 countries, including Western and non-Western regions, Treas, Van der Lippe, and Tai (2011) found that housewives were happier than full-time employed wives, although there was no difference found between housewives and part-time employed wives in the level of happiness.

While these results are suggestive and advance our understanding of women's work lives, the current study pays special attention to the effect of macrolevel gender climate. Societal-level gender norms may determine the meaning of women's employment, whether rewarding or detrimental. Placing this relationship in a more male-dominated, traditional gender climate may depict the significance of its impact, and the present study uses East Asia, with its long history of patriarchal dominance, as the scope for its analysis. 


\section{Wives' Employment in an East Asian Context}

\section{East Asian Families and Traditional Women's Roles}

Although all East Asian countries have reached more egalitarian gender relations in recent decades, they have maintained a more traditional gender climate as compared to Western societies. Partly due to the Confucius ideology that has influenced this part of the world historically, women's disadvantageous social positions have become normalized and social expectations towards men and women remain more rigidly defined by gender. Childrearing is considered as the central role of women, and even women strongly agree with this role (Ochiai et al. 2008). Another influence of Confucianism is the emphasis on filial responsibility and intergenerational relationships, which puts caring roles firmly in the realm of women. Therefore, East Asian women are more likely to bear excessive family responsibilities.

In this more traditional context regarding gender, women's non-traditional role - full-time employment - is expected to be detrimental to their psychological well-being in many ways. First, since the social expectation towards women's responsibilities for care work is more rigid and normative, paid employment may be considered as non-conforming, deviant behavior much more in Asian societies as compared to that of a Western context. In other words, the positive effect of conforming to the norm may be stronger in East Asia than in societies where the normative pressure is less pronounced. In addition, East Asian women may experience work-family conflict more excessively, especially when those women work full-time, because they are the central figures of care work. Family responsibilities are disproportionately placed on women, even when paid employment is encouraged in order to bring a second income into the household. Lastly, the fact that Asian marriages are still more institutional rather than companionship (Burgess, Locke, and Thomas 1971) may add to this picture. Since social expectation towards men's role as the breadwinner is also stronger, wives who hold more traditional attitudes yet their households need the second income, may be dissatisfied with taking non-traditional responsibilities.

\section{Differences in Female Labor Force Participation Patterns}

Although the gender climate in East Asian countries is more traditional than Western nations in general, these countries are not exceptions in these times of global social changes that are moving towards more gender equality. Especially in terms of female labor force participation, some parts of the East Asian regions are considered as equivalent to, or following the "Western" pattern that 
is represented by the United States or Scandinavian nations. For example, female labor force participation rates are higher and more consistent over the life course in China and Taiwan (Ochiai et al. 2008; Yu 2015). Although women's family responsibilities, especially the roles of mothers, are still strongly expected, it seems that their paid labor force participation is not detracted by their family responsibilities. According to Ochiai et al. (2008), female participation in the labor market in China and Taiwan does not decline at reproductive ages (i.e., in their twenties) while it shows a temporary decline in Japan and South Korea, which is called the "M" shaped pattern. This pattern shows that many women exit the labor market when they marry or have their first child, and reenter the labor force after their children have grown to some degree. These women who return to the paid labor force typically work part-time, because the time they were absent from the labor market prevents them from going back to the work place they used to work before their exit. Part-time employment also allows them to balance between work and family responsibilities. Meanwhile, women who continue to work during the child-rearing and caring ages are more likely to be able to maintain their work careers.

While the social expectation towards women to fulfill a mother's role may be similar among these four countries, the distinctive differences in their labor force participation is expected to affect how people perceive married women's employment, resulting in how married women themselves perceive their own employment status. In China and Taiwan women's full-time employment may be considered compatible with mother's caring roles, while it is not the case (even so far as to be considered as "deviant") in Japan and South Korea. This difference may eventually affect their marital satisfaction.

\section{Wives' Employment and Their Marital Satisfaction}

As noted in previous research, women's employment may have a positive, negative, or neutral effect on their subjective well-being. Meanwhile, wives' employment status may have a more consistent effect on the specific domain of well-being, such as marriage. Work-family conflict and time bind caused by employment are expected to affect marital satisfaction more than general well-being. Especially in East Asian societies where the cultural emphasis on collective interests for the family over an individual remains strong, focusing on the specific domain of satisfaction may explain the relationship between wives' work status and their subjective well-being more clearly.

In East Asian societies, where social expectation towards women's domestic responsibilities is still prominent, the benefit of being full-time housewives, who do not face challenges to fulfill work roles, may be even stronger. Part-time 
work, as compared to full-time work, may also have a positive effect on marital satisfaction among women if they are expected to bring a second income and need to juggle between work and family roles, especially in the countries where part-time work is more common for married women. Wives' employment may matter more to their well-being, especially marital satisfaction, in the context of a greater degree of gender inequality and male-dominance.

\section{Data and Methods}

\section{Data}

The current study utilizes the dataset from the East Asian Social Survey (EASS) 2006: Family Module. The EAss is a collaboration among four East Asian countries: China, Japan, South Korea, and Taiwan, and is based on the General Social Survey (GSS). While each country conducts data collection for the GSs, they collect additional information for the EAss's specific module bi-yearly. The EASS 2006 module is related to family issues, which provides a wide range of information regarding East Asian families.

For the purposes of examining women's well-being in relation to their nontraditional role of work in a more gender-traditional context, the current study focuses on married female respondents from the four countries whose age is between 18 and 65 years old. In addition, the self-employed are excluded from the analysis, because self-employment is different from paid employment, especially in work schedule flexibility, which is expected to affect married women's psychological well-being significantly. In order to investigate whether there are any differences in the countries, the analysis is conducted for the four countries separately. The final sample size for each country is: 871 for China, 427 for Japan, 481 for South Korea, and 445 for Taiwan.

\section{Measures}

The dependent variable for this study is marital satisfaction of individuals. This variable is measured by a single question, "Considering all things together, how would you describe your marriage? Would you say that you are very satisfied or dissatisfied with your marriage?". The response categories range from 1 (Very satisfied) to 5 (Very dissatisfied). The responses are reverse-coded so that the high score indicates that the respondent is more satisfied.

The key independent variable is employment status. The responses for this variable are drawn directly from the question asking the respondents' current employment status. The recoding scheme follows that of Treas et al. (2011), and 
three dummy variables are created: "employed part-time," "homemaker,"1 and "not in labor force,"2 with "employed full-time" being the reference category.

Other independent variables include the respondent's gender role attitudes, the husband's housework participation, the number of people in the household, and the husband's employment status. Gender role attitudes are measured by the following three statements: "It is more important for a wife to help her husband's career than to pursue her own career," "A husband's job is to earn money; a wife's job is to look after the home and family," and "During economic recession, it is all right for women to be laid-off than prior to men," with the response categories ranging from 1 (Strongly agree) to 7 (Strongly disagree). The responses from these three questions are averaged and the higher score indicates more egalitarian attitudes. Husband's housework participation is measured from five items: preparing the evening meal, doing the laundry, cleaning the house, shopping for groceries, and taking out the garbage. The questions ask the respondents "How often does your spouse do the followings?" and the respondents are supposed to answer using a 7 point scale, 1 (Almost every day) to 7 (Never). The average among 5 items is calculated after the responses are reverse-coded so that the higher score indicates more husband's participation. The number of household members is directly drawn from the question, "How many family members, including yourself, live at your residence?" Lastly, a dummy variable is created for the husband's employment status whereby the respondents with unemployed husbands are coded 1 , and those with employed husbands are coded 0 .

Additionally, several control variables are included: household income, respondent's education, husband's education, and respondent's age. The question regarding household income is asked categorically in Japan and Taiwan while in China and South Korea the exact amount, is asked, and therefore the midpoints of each category is taken for Japanese and Taiwanese data. After the modification, the logged annual household income is calculated for each country. The respondent's and husband's education are measured in years. Finally, for the respondent's age, an actual age (divided by 100) and a squared term of age/10o are used to see whether there is a curvilinear relationship with marital satisfaction in the East Asian societies. The squared term of age is dropped from the model when the coefficient is not statistically significant and then the regression model is re-run without the squared term.

1 In this category, "Helping family member," "Retired," and "Housewife" are included.

2 In this category, "Unemployed," "Student, school, vocational training," "Permanently disabled," and "Other" are included. 


\section{Analytical Procedures}

The analysis is conducted in the following steps: in order to capture the similarities and differences in the marital satisfaction among East Asian women, the current study analyzes the distribution of marital satisfaction by country. Next, the descriptive statistics of data are examined for the four countries separately, focusing on women's employment status in addition to the other variables related to marriage and family. Lastly, the Ordinal Logit Regression Models are estimated by country, in order to examine the relationship between women's marital satisfaction and their employment status and other possible predictors in East Asian context.

\section{Findings}

\section{Descriptive Results}

Table 1 compares the distribution of women's marital satisfaction among China, Japan, South Korea, and Taiwan, without controlling for individual and family characteristics. First, all countries show a negatively skewed distribution, meaning most respondents answered their marital satisfaction towards the higher end. More obvious differences are observed between non-Chinese originated countries and Chinese-originated countries. The distribution of marital satisfaction is more towards the higher end, with the category 4 (=Satisfied) representing over $50 \%$ of the respondents from China and Taiwan, while in Japan and South Korea it is an almost evenly split distribution between 3 (=Neutral) and 4 (=Satisfied). This trend also presented in the sample characteristics (Table 2), as the mean marital satisfaction is higher in Taiwan $(=3.94)$ and China (=3.87), followed by South Korea (=3.55) and Japan (=3.47). On average, marital satisfaction of East Asian women is somewhere between neither dissatisfied nor satisfied but more towards the satisfied side. ${ }^{3}$

Table 2 compares the sample characteristics for the four countries separately. More clear differences are observed in wives' employment status here. While two thirds of Chinese wives, and almost half of Taiwanese wives, are employed full-time, full-time employed wives are only 20 to 30 percent in Japan and South Korea. Additionally, the proportion of full-time housewives is largest in South Korea $(=56.96 \%)$ and Japan $(45.90 \%)$. Although the proportion of full-time housewives is also high in Taiwan (=41.57), China has the lowest rate of homemakers $(=15 \cdot 15 \%)$. Another striking difference is the distinctively

3 The difference is statistically significant at .05 level between the following countries: China and Japan, China and South Korea, Japan and Taiwan, and South Korea and Taiwan. 
TABLE 1 Distribution of marital satisfaction by country

\begin{tabular}{|c|c|c|c|c|}
\hline & $\begin{array}{l}\text { China } \\
(\mathrm{N}=871)\end{array}$ & $\begin{array}{l}\text { Japan } \\
(\mathrm{N}=427)\end{array}$ & $\begin{array}{l}\text { S.Korea } \\
(\mathrm{N}=481)\end{array}$ & $\begin{array}{l}\text { Taiwan } \\
(\mathrm{N}=445)\end{array}$ \\
\hline \multicolumn{5}{|l|}{ Marital Satisfaction } \\
\hline Very dissatisfied & $0.57 \%$ & $2.81 \%$ & $3.12 \%$ & $1.12 \%$ \\
\hline 2 & $3 \cdot 79 \%$ & $11.94 \%$ & $6.65 \%$ & $5.84 \%$ \\
\hline 3 & $15.96 \%$ & $35.60 \%$ & $38.05 \%$ & $12.13 \%$ \\
\hline 4 & $66.93 \%$ & $34.66 \%$ & $36.80 \%$ & $59 \cdot 33 \%$ \\
\hline Very satisfied & $12.74 \%$ & $14.99 \%$ & $15 \cdot 38 \%$ & $21.57 \%$ \\
\hline
\end{tabular}

TABLE 2 Sample characteristics by country (mean $(S D) / \%)$

\begin{tabular}{lllll}
\hline & $\begin{array}{l}\text { China } \\
(\mathrm{N}=871)\end{array}$ & $\begin{array}{l}\text { Japan } \\
(\mathrm{N}=427)\end{array}$ & $\begin{array}{l}\text { S.Korea } \\
(\mathrm{N}=481)\end{array}$ & $\begin{array}{l}\text { Taiwan } \\
(\mathrm{N}=445)\end{array}$ \\
\hline $\begin{array}{l}\text { Dependent Variable } \\
\text { Marital Satisfaction (1-5) }\end{array}$ & $3.87(0.69)$ & $3.47(0.98)$ & $3.55(0.94)$ & $3.94(0.82)$
\end{tabular}

\section{Independent Variables}

Respondent's employment

status

$\begin{array}{lcccc}\text { Full-time (reference) } & 66.48 \% & 20.61 \% & 28.07 \% & 49.44 \% \\ \text { Part-time } & 14.35 \% & 31.62 \% & 7.90 \% & 3.82 \% \\ \text { Homemaker } & 15.15 \% & 45.90 \% & 56.96 \% & 41.57 \% \\ \text { Not in labor force } & 4.02 \% & 1.87 \% & 7.07 \% & 5.17 \% \\ \text { Gender role attitudes }(1-7) & 3.88(1.03) & 4.42(1.00) & 4.25(1.30) & 4.22(1.25) \\ \text { Husband's housework }(1-7) & 4.40(1.82) & 2.57(1.49) & 3.13(1.62) & 3.43(1.70) \\ \text { Number of people in H H } & 4.45(2.17) & 3.91(1.39) & 3.90(0.97) & 4.56(1.66) \\ \text { Unemployed husband } & 28.93 \% & 14.99 \% & 9.15 \% & 22.02 \% \\ & & & & 15.08(0.75) \\ \text { Logged Household income } & 9.86(0.79) & 15.55(0.94) & 136(0.84) \\ \text { Respondent's years of } & 10.20(11.83) & 12.99(6.04) & 13.68(9.87) & 12.20(9.87) \\ \text { education } & & & & \\ \text { Husband's years of } & 9.83(2.96) & 13.21(2.38) & 14.70(9.80) & 12.27(3.76) \\ \text { education } & & & & \\ \text { Respondent's age } & 42.96(11.47) & 47.43(10.45) & 41.81(8.60) & 43.60(9.88)\end{array}$


higher rate of part-time employment among Japanese wives - almost one third of the sample. From these differences, it is reasonable to conclude that being a full-time housewife is more normative in Japan and South Korea, while fulltime employment is more likely for Chinese and Taiwanese wives.

Meanwhile, gender role attitudes show interesting results. While China has the highest full-time employment rate among the four countries, their gender role attitudes are the most traditional. On the other hand, Japanese wives' gender role attitudes are the most egalitarian while either part-time employment or full-time housewife is more common. Overall, East Asian women are somewhat neutral regarding traditional gender roles. ${ }^{4}$ The results regarding husband's housework participation reflect the differences in wives' employment status more. Husband's housework participation is the highest in China $(=4.40)$ where the full-time employment rate among wives is the highest, while it is the lowest in Japan (=2.57). However, the overall average of husband's participation is not very high, and even Chinese husbands' participation is only between "about once a month (=4)" and "about once a week (=5)." Many East Asian husbands do not participate in housework regularly - less than once a month. The size of the household is around 4 people among the four countries, with no significant differences. The proportion of husbands with no job is between about $10 \%$ (=South Korea) and 30\% (=China). The sample is limited to wives who are between 18 and 65 year old and some wives may have husbands who have already retired.

\section{Regression Results}

Table 3 presents the results from the Ordinal Logit Model estimates regarding the relationship between women's marital satisfaction and the possible predictors in East Asian countries. The first question of the current study is whether or not being a housewife is still the norm, and the statistically significant relationship between wives' employment status and their marital satisfaction is found in China and Taiwan but no association is found in Japan and South Korea. The positive relationship between being a housewife and marital satisfaction is only found in Taiwan. In other words, housewives are more satisfied with their marriage than full-time employed wives in Taiwan, although there is no statistically significant difference between being a housewife and being employed part-time, nor between full-time employment and part-time employment. While in China, the relationship is in the opposite direction - parttime employed wives are less satisfied with their marriage than those who are

4 The difference is statistically significant at .05 level between the following countries: China and Japan, China and South Korea, China and Taiwan, and Japan and Taiwan. 
TABLE 3 Ordinal logit models predicting marital satisfaction by country

\begin{tabular}{|c|c|c|c|c|c|c|c|c|}
\hline \multirow[b]{2}{*}{ Variable } & \multicolumn{2}{|c|}{ China $(\mathrm{N}=871)$} & \multicolumn{2}{|c|}{$\operatorname{Japan}(\mathrm{N}=427)$} & \multicolumn{2}{|c|}{ S.Korea $(\mathrm{N}=481)$} & \multicolumn{2}{|c|}{ Taiwan $(\mathrm{N}=445)$} \\
\hline & $b$ & $S E$ & $b$ & $S E$ & $b$ & $s E$ & $b$ & $s E$ \\
\hline \multicolumn{9}{|l|}{ Respondent's } \\
\hline \multicolumn{9}{|l|}{ employment status } \\
\hline Part-time & $-.612^{* *}$ & .205 & -.084 & $.25^{8}$ & .176 & .349 & -.116 & .501 \\
\hline Homemaker & -.349 & .209 & .300 & .256 & .258 & .210 & $.568^{*}$ & .225 \\
\hline Not in labor force & -.200 & .370 & -.664 & .684 & .090 & .375 & .257 & $.45^{1}$ \\
\hline $\begin{array}{l}\text { Gender role attitudes } \\
(1-7)\end{array}$ & .061 & .070 & $-.242^{*}$ & .098 & $-.162 *$ & .073 & -.002 & .087 \\
\hline $\begin{array}{l}\text { Husband's housework } \\
(1-7)\end{array}$ & .035 & .039 & $.141 *$ & .063 & $.302^{* * *}$ & .056 & $.181^{* * *}$ & .057 \\
\hline $\begin{array}{l}\text { Number of people in } \\
\mathrm{HH}\end{array}$ & .007 & .033 & $-.205^{* *}$ & .067 & $-.212 *$ & .091 & -.033 & .059 \\
\hline Unemployed husband & .091 & .187 & $-.25^{1}$ & .289 & -.067 & .345 & -.388 & .273 \\
\hline $\begin{array}{l}\text { Logged Household } \\
\text { income }\end{array}$ & .096 & .101 & $.269 *$ & .105 & $.449^{* *}$ & .138 & .178 & .128 \\
\hline $\begin{array}{l}\text { Respondent's years of } \\
\text { education }\end{array}$ & $.001^{* *}$ & .006 & -.004 & .015 & -.003 & .009 & $-.020^{*}$ & .010 \\
\hline $\begin{array}{l}\text { Husband's years of } \\
\text { education }\end{array}$ & .083 & .028 & .007 & .042 & .013 & .009 & .053 & .030 \\
\hline Respondent's age & -.635 & .762 & -1.613 & .979 & $-4.914^{* * *}$ & 1.184 & -1.832 & 1.191 \\
\hline
\end{tabular}

${ }^{* * *} \mathrm{p}<0.001 ;{ }^{* *} \mathrm{p}<0.01 ;{ }^{*} \mathrm{p}<0.05$

employed full-time, while the difference between full-time employed wives and full-time housewives is not statistically significant (although the association is negative between being a housewife and marital satisfaction as compared to being employed full-time). On the other hand, employment status does not either negatively or positively impact married women's satisfaction in Japan and South Korea, the opposite of what the current study predicted.

Meanwhile, other factors are related more significantly with married women's satisfaction, especially in Japan and South Korea. Having more egalitarian gender role attitudes is negatively associated with women's marital satisfaction in Japan and South Korea, while gender role attitudes do not appear to matter to Chinese and Taiwanese women. Husband's housework participation is also positively associated with wives' marital satisfaction in Japan, South 
Korea, and Taiwan. The household size is negatively associated with wives' marital satisfaction in Japan and South Korea, in a manner that wives are less satisfied with their marriage as the number of family members rises. Overall, the results show that wives' employment is associated with their marital satisfaction but not in all countries, nor in the expected direction. The results also illustrate that other factors are associated with marital satisfaction in some countries.

Lastly, some control variables show statistically significant relationships with marital satisfaction of East Asian wives. Household income is positively associated with Japanese and South Korean women's marital satisfaction. Respondent's education is also positively associated with Chinese women's marital satisfaction, while it is negatively associated in Taiwan. Finally, South Korea is the only country where there is a significant relationship between respondent's age and her marital satisfaction - their satisfaction decreases as they age.

\section{Discussion and Conclusion}

The current study investigated the effect of wives' employment status on their marital satisfaction in East Asian countries. The countries in question have been under the influence of Confucianism ideologies that emphasize strictly defined gender relations and women's domestic responsibilities. Therefore, employment, the non-traditional role for wives, was expected to be negatively associated with women's marital satisfaction, while being a housewife (presumed to be the norm) was expected to lead to a higher level of satisfaction.

Although China and Taiwan have more closely followed Western nations, in terms of female paid labor force participation, their gender role attitudes still remain more traditional as compared to their Western counterparts. Japan and South Korea, on the other hand, are far behind in gender equality in many areas, including that of employment opportunities and work conditions for women with family responsibilities. While they have accomplished the greater degree of industrialization and modernization, these two societies have not yet reached the stage of "de-housewifezation" of women (Ochiai 2008). With this unique combination, the greater degree of modernization and yet very traditional gender norms embedded in East Asian societies, the relationship between married women's work role and their well-being observed in Western contexts is shown to not be applicable in East Asian countries. Building upon previous research focused on Western countries, the current investigation illustrated the complexity of East Asian women's life experience. 
Contrary to expectations, the countries that showed a statistically significant relationship between wives' employment and their marital satisfaction are China and Taiwan and, even more surprising is the fact that the two countries differ from each other. The pattern in Taiwan confirmed the findings from Treas et al. (2013): being a housewife is positively associated with wives' marital satisfaction. Given the fact that female paid labor force participation is higher in Taiwan, this is a surprising result. However, in China, full-time employed wives are more satisfied than part-time employed wives, another interesting result in a gender traditional context such as East Asia. In China, full-time employment may be the norm for women, especially given that most wives are employed full-time as the sample characteristics shows. Interestingly, Chinese women's gender role attitudes are not necessarily more egalitarian than those from the other three countries, as the sample characteristics showed. This mismatch between the attitude and the behavior may add another angle to our understanding of gender roles in the East Asian context.

Another interesting finding is that in Japan and South Korea, where married women's labor force participation is more limited, their employment status did not affect their marital satisfaction. Instead, other gender- and family-related factors seem to matter more to their subjective well-being. Having more egalitarian gender role attitudes is negatively associated with women's marital satisfaction in Japan and South Korea, but it does not affect Chinese and Taiwanese women. Japanese and South Korean women are also more egalitarian regarding gender roles than those in China and Taiwan. In addition, having more family members is negatively associated with marital satisfaction of Japanese and South Korean wives but not that of Chinese and Taiwanese wives. This is probably because having more people in the household may be equal to having more people the wives are required to take care of in Japan and South Korea, while it may mean having more people to help wives in China and Taiwan. These results imply that women from Japan and South Korea may have relatively more egalitarian gender role attitudes as compared to those in China and Taiwan, but the social circumstances surrounding gender roles such as women's caring role and employment are still traditional, and therefore women with more egalitarian gender role attitudes are less satisfied. Husband's housework participation also improved wives' marital satisfaction in Japan and South Korea.

From these results, it is reasonable to say that the division of labor is more egalitarian among Chinese couples and therefore Chinese wives have a higher level of marital satisfaction. A similar conclusion may be applicable to Taiwanese couples, although full-time housewives are more satisfied than 
full-time employed wives in Taiwan. While working part-time is expected to contribute wives' marital satisfaction due to shorter work hours leading to the ability to balance between work and family responsibilities, part-time employed wives are not more satisfied than full-time employed wives in any country, even in Japan where part-time employment is more common. In this study, being employed part-time is rather associated negatively with Chinese wives' marital satisfaction as compared to full-time employment. It is interesting to mention that the effect of full-time employment varies among wives from China and Taiwan, where a similar pattern of division of labor and aggregated gender ideologies is observed. Furthermore, a seeming mismatch between gender role attitudes and reality surrounding married women's employment, may be contributing to a lower level of marital satisfaction in Japan and South Korea, rather than simply employment status itself.

In future studies, addressing issues such as selection bias and the use of cross-sectional data would greatly advance our understanding of women's employment and a sense of well-being within the marriage. It is possible that wives with more satisfying marriages may be more likely to stay home in Taiwan, or be more likely to take a full-time job in China. Additional research using panel data should clarify the causal directions of the relationship. Another limitation is the lack of data regarding availability of childcare services, either from public or familial resources. Since East Asian countries hold culturally strong expectation towards mother's role as a child caretaker, whether wives have a childcare resource should be an important indicator of marital satisfaction in relation to their employment.

Even so, by focusing on these four East Asian countries, the current investigation shed significant light on how women's work lives and their well-being may differ, even among countries that are ideologically similar. This suggests that it is critical that future studies use data from a larger selection of countries and different domains of life satisfaction in order to improve our understanding of the relationship between wives' employment and their well-being.

\section{References}

Allen, Tammy D., David E. L. Herst, Carly S. Bruck, and Martha Sutton. 2000. "Consequences Associated with Work-To-Family Conflict: A Review and Agenda for Future Research." Journal of Occupational Health Psychology 5: 278-308.

Barnett, Rosalind C., and Janet S. Hyde. 2001. "Women, Men, Work, and Family: An Expansionist Theory." American Psychologist 56: 781-796. 
Bianchi, Suzanne M., Melissa A. Milkie, Liana C. Sayer, and John P. Robinson. 2000. "Is Anyone Doing the Housework? Trends in the Gender Division of Household Labor." Social Forces 79:191-228.

Booth, Alison L., and Jan C. van Ours. 20og. "Hours of Work and Gender Identity: Does Part-Time Work Make the Family Happier?" Economica 76: 176-196.

Booth, Alison L., and Jan C. van Ours. 2013. "Part-Time Jobs: What Women Want?" Journal of Population Economics 26: 263-283.

Burgess, Ernest W., Harvey J. Locke, and Mary M. Thomas. 1971. The Family: From Institution to Companionship, 4th edn, New York: Van Nostrand Reinhold Company. Campione, Wendy. 2008. "Employed Women's Well-Being: The Global and Daily Impact of Work." Journal of Family and Economic Issues 29: 346-361.

Coltrane, Scott. 200o. "Research on Household Labor: Modeling and Measuring the Social Embeddedness of Routine Family Work." Journal of Marriage and the Family 64: 1208-1233.

Demerouti, Evangelia, and Sabine Geurts. 2004. "Towards a Typology of Work-Home Interaction." Community, Work \& Family 7: 285-309.

DeVault, Marjorie L. 1991. Feeding the Family: The Social Organization of Caring as Gendered Work. Chicago: University of Chicago Press.

East Asian Social Survey. 2006. East Asian Social Survey Data Archive (http://eassda .org/).

Hill, Jeffrey E., Chongming Yang, Alan J. Hawkins, and Maria Ferris. 2004. "A CrossCultural Test of the Work-Family Interface in 48 Countries." Journal of Marriage and Family 66: 1300-1316.

Klumb, Petra L., and Thomas Lampert. 2004. "Women, Work, and Well-Being 1950-2000: A Review and Methodological Critique." Social Science \& Medicine 58: 1007-1024.

Marks, Stephen R., and Shelley M. MacDermid. 1996. "Multiple Roles and the Self: A Theory of Role Balance." Journal of Marriage and Family 58: 417-432.

Moore, Gwen. 1990. “Structural Determinants of Men's and Women's Personal Networks." American Sociological Review 55: 726-735.

Nomaguchi, Kei M., Melissa A. Milkie, and Suzanne M. Bianchi. 2005. "Time Strains and Psychological Well-Being: Do Dual-Earner Mothers and Fathers Differ? Journal of Family Issues 26, 756-92.

Ochiai, Emiko. 2008. "Researching Gender and Childcare in Contemporary Asia." Pp. 1-30 in Asia's New Mothers: Crafting Gender Roles and Childcare Networks in East and Southeast Asian Societies, edited by E. Ochiai and B. Molony. Kent: Global Oritantal.

Ochiai, Emiko., Mari Yamane, Yasuko Miyazaka, Weihong Zhou, Setsuko Onode, Nachiko Kiwaki, Michiyo Fujita, and Hong Sang Ook. 2008. "Gender Roles and Childcare Networks in East and Southeast Asian Societies." Pp. 31-70 in Asia's New 
Mothers: Crafting Gender Roles and Childcare Networks in East and Southeast Asian Societies, edited by E. Ochiai and B. Molony. Kent: Global Oritantal.

Ross, Catherine E., John Mirowsky, and Karen Goldsteen. 1990. "The Impact of the Family on Health: The Decade Review." Journal of Marriage and the Family 52: 1059-1078.

Ross, Catherine. E., and Barbara F. Reskin. 1992. "Education, Control at Work, and Job Satisfaction." Social Science Research 21: 134-148.

Stevenson, Betsey, and Justin Wolfers. 2009. "The Paradox of Declining Female Happiness." American Economic Journal: Economic Policy 1: 190-225.

Thoits, Peggy. 1983. "Multiple Identities and Psychological Well-Being: A Reformulation and Test of the Social Isolation Hypothesis." American Sociological Review 48: 174-187. Tilly, Chris. 1996. Half a Job: Bad and Good Part-Time Jobs in a Changing Labor Market. Philadelphia: Temple University Press.

Treas, Judith, Tanja van der Lippe, and Tsui-o Chloe Tai. 2011. "The Happy Homemaker? Married Women's Well-Being in Cross-National Perspective." Social Forces 90:111-132. Wilk, Piotr. 2001. "Women's Employment Transitions and Changes in Psychological Distress." Canadian Studies in Population 28: 513-533.

Yu, Wei-hsin. 2015. "Women and Employment in Taiwan." Taiwan-U.s. Quarterly Analysis 19. Retrieved from https://www.brookings.edu/opinions/women-andemployment-in-taiwan/. 